\title{
Association of XRCC1 rs1799782 and ERCC2 rs13181 Polymorphisms with Glioma Risk: A Systematic Review and Meta-Analysis
}

Cléciton Braga Tavares

Federal University of Piaui

Francisco Adelton Alves-Ribeiro

Rede Nordeste de Biotenologia

Elmo de Jesus Nery Junior

Federal University of Piaui

Rodrigo Jose de Vasconcelos-Valença

Federal University of Piaui

Larysse Cardoso Campos-Verdes

Federal University of Piaui

Francisca das Chagas Sheyla Almeida Gomes-Braga

Federal University of Piaui

Pedro Vitor Lopes-Costa

Universidade Federal do Piaui

Alesse Ribeiro dos Santos

Universidade Federal do Piaui

André Luiz Pinho-Sobral

Federal University of Piaui

Viriato Campelo

Federal University of Piaui

Arquimedes Cavalcante Cardoso

Universidade Federal do Piaui

\section{Emerson Brandao Sousa}

Federal University of Piaui

Renato de Oliveira Pereira

Federal University of Piaui

Luiz Henrique Gebrim

Rede Nordeste de Biotecnologia

Benedito Borges da Silva ( $\sim$ beneditoborges@globo.com )

Universidade Federal do Piaui https://orcid.org/0000-0002-9542-7538

Research article 
Keywords: XRCC1, Arg194Trp polymorphism, ERCC2, Lys751GIn polymorphism, gliomas meta-analysis

Posted Date: August 19th, 2020

DOI: https://doi.org/10.21203/rs.3.rs-56338/v1

License: (c) (7) This work is licensed under a Creative Commons Attribution 4.0 International License. Read Full License 


\section{Abstract}

\section{Background}

Gliomas are the most common primary tumors of the central nervous system with unclear etiology, however hereditary factors may play important roles in the development of gliomas with mutations and single nucleotide polymorphisms (SNPs) being prominent among the genetic changes. this systematic review and meta-analysis assess the association of XRCC1 (rs1799782) and ERCC2 (rs13181) gene polymorphisms and glioma risk.

\section{Methods}

This study included articles indexed in the PUBMED and EMBASE databases published during the past 15 years. Preferred Reporting Items for Systematic Reviews and Meta-Analyses (PRISMA) guidelines were followed. The PICOS model was used to develop the inclusion criteria and search terms. This review was recorded at PROSPERO International prospective register of systematic reviews, ID 196173. The META-MAR V2.7.0 metaanalysis calculator was used for the statistical analysis with p-values $<0.05$ being considered statistically significant. Dichotomous data are presented as odds ratios (OR) with a $95 \%$ confidence interval (Cl). Statistical heterogeneity was measured using the $\mathrm{I}^{2}$ test and $\mathrm{I}^{2}>50 \%$ were regarded as high heterogeneity. Funnel plots, Begg (BT) and Egger Tests (ET) were used to assess publication bias $(\mathrm{p}<0.1)$.

\section{Results}

Literature review identified 10 articles on ERCC2 gene rs13181 variant and 11 on XRCC1 rs1799782. The metaanalysis identified a risk for gliomas for the TT genotype of the XRCC1 rs1799782 SNP in Asians (OR: 1.59, 95\% Cl: $\left.1.3-1.93 ; \mathrm{p}=0.006 ; \mathrm{I}^{2} 13.1 \%\right)$. ERCC2 rs13181 polymorphisms identified as risks for gliomas were AC genotypes in Asians (OR: 2.06, 95\% Cl: 1.75-1.42; $\mathrm{p}=0.00057 ; \mathrm{I}^{2}$ 91.1\%) and Caucasians (OR: $1.16,95 \%$ Cl: $1.01-$ $1.31 ; p=0.02 ; I^{2} 12.2 \%$ ), and CC genotypes in Caucasians (OR: 2.06, 95\% Cl: $1.75-1.42 ; p=0.0001 ; I^{2} 98.9 \%$ ).

\section{Conclusions}

TT genotypes of the XRCC1 rs1799782 SNP in Asians, AC genotypes of ERCC2 rs13181 polymorphisms in Asians and Caucasians, and CC genotypes of ERCC2 rs13181 polymorphisms in Caucasians were associated with increased risk for gliomas that may benefit these patients with early diagnostic and therapeutic strategies.

\section{Background}

Gliomas are the most common primary tumors of the central nervous system, representing approximately $80 \%$ of all malignant central nervous system tumors. There are four histological subtypes of which astrocytomas are the most prevalent. According to the World Health Organization (WHO) 2010 classification, astrocytomas can be stratified into four grades with grades I and II being low grade or benign and grades III and IV being high grade or malignant. The latter grades are highly aggressive and present a poor prognosis, even when adequately treated with surgical resection, chemotherapy, and radiotherapy [1-5].

Many environmental and lifestyle factors are considered to be associated with increased risk for the development of gliomas, including some occupations, exposure to ionizing radiation, and smoking, among 
others. Hereditary factors may also play an important role in the development of gliomas as genetic studies have identified several genes that may be associated with the onset and/or growth of these tumors [5-7].

Among several genetic changes, mutations and polymorphisms stand out and may result in inter-individual differences in susceptibility to diseases and response variations to drugs and environmental factors. Single nucleotide polymorphisms (SNPs) are the simplest and most common form of polymorphism, characterized as the change of a single nitrogenous base at a frequency greater than $1 \%$ and is sometimes associated with the insertion or deletion of one or more nucleotides [8].

Multiple genes encode proteins involved in correcting possible DNA errors, including the X-ray repair crosscomplementing group 1 (XRCC1) and excision repair cross-complementation group 2 (ERCC2). XRCC1 encodes proteins that repair base excisions and single-strand breaks in DNA while the $E R C C 2$ gene encodes proteins that are involved in transcription-coupled nucleotide excision repair. These represent three of the main mechanisms of DNA repair, preventing mutations that can lead to the development of cancer in different organs. However, the presence of SNPs in these genes can alter or inhibit repair mechanisms, resulting in mutations and increased risks for the development of gliomas $[8,9]$.

Numerous studies have been published on these genes and their various polymorphisms, but they often contain conflicting results. There is a need for greater understanding of the pathways involved in the regulation of the aberrant growth of glial neoplasms. This need led us to conduct a systematic review of the literature and to perform a meta-analysis regarding XRCC1 rs1799782 and ERCC2 rs13181 polymorphisms in effort to determine their association with the risk of healthy individuals developing gliomas.

\section{Methods}

This study followed the Preferred Reporting Items for Systematic Reviews and Meta-Analysis (PRISMA) standards and used a targeted search to identify and retrieve relevant articles [9]. The Population, Intervention, Comparison, Outcome and Study design (PICOS) model was used for developing the inclusion criteria and search terms. This review was recorded at PROSPERO International prospective register of systematic reviews, ID 196173.

\section{Literature search}

The PUBMED and EMBASE databases were searched for case-controls articles published between January 2005 and April 2020 with an association of XRCC1 rs1799782 or ERCC2 rs13181 (intervention) and increased or decreased risk (comparison) of developing gliomas (outcome) in healthy individuals (population). The following search terms and Booleans were used: ("SNP" OR "polymorphism" OR "single nucleotide polymorphism") AND ("gliomas" OR "glioma" OR "astrocytoma" OR "glioblastoma") AND ("XRCC1 gene" OR "ERCC2 gene"). The search process included only articles in English.

\section{Selection Criteria}

The inclusion criteria were: a) case-control studies, b) articles on the risk of developing gliomas for participants free from the disease, c) studies of human beings, and d) studies on SNPs of the XRCC1 and ERCC2 genes. The 
exclusion criteria were: a) irrelevant studies, b) repeated publications, c) articles with only abstract being available, d) case reports/case series, e) editorials, f) comments, g) literature reviews, h) polymorphisms in tumors other than gliomas, i) polymorphisms of the XRCC1 gene other than rs1799782, j) polymorphisms of the ERCC2 gene other than rs13181, and I) letters to the editor.

To expand the scope of the evaluation, all articles were inspected by two experienced investigators. The data were extracted and compiled by one reviewer using a standardized abstraction form and independently verified by the second reviewer. In the event of any disagreements, the issues were resolved by consulting with two additional reviewers for consensus.

\section{Quality assesment}

The quality of the methodology used in the published reports included in our study was assessed using the Quality Assessment Tool for Quantitative Studies [10]. This tool globally rated the studies as weak, moderate, or strong by evaluating potential selection bias, study design, confounding factors, concealment, data collection methodology, and withdrawal and dropout reports. Component ratings were scored according to the criteria specified in the dictionary accompanying the assessment tool [10]. The global quality assessment rating of each study was determined by evaluating the six component classifications [10]. The studies without any weak ratings and with at least four strong ratings were considered strong. Those with one weak and less than four strong ratings were considered moderate. Finally, those with two or more weak ratings were considered weak.

\section{Data analysis}

Statistical analysis was conducted using the META-MAR V2.7.0 meta-analysis calculator and p-values $<0.05$ were considered statistically significant. Dichotomous data are presented as odds ratios (OR) with a 95\% confidence interval $(\mathrm{Cl})$. Statistical heterogeneity was measured using the $\mathrm{I}^{2}$ test and $\mathrm{I}^{2}>50 \%$ were regarded as high heterogeneity. Funnel plots, Begg (BT) and Egger Tests (ET) were used to assess publication bias with significance level established at $p<0.1$.

\section{Results}

A total of 933 published articles were identified by searching the PUBMED and EMBASE databases; however, only 160 of the articles met the inclusion criteria. After being evaluated by the two reviewers, 139 studies were excluded and only 21 were included in the systematic review. Ten of the included papers were on ERCC2 rs13181 and eleven were on XRCC1 rs1799782 (Fig. 1). All the studies included in our analysis were considered to be of moderate quality according to the evaluation tool (Table 1). 
Table 1

Quality assessment of the reports included in the current study.

\begin{tabular}{|c|c|c|c|c|c|c|c|}
\hline \multirow[t]{2}{*}{ Study } & \multicolumn{6}{|c|}{ Component Ratings } & \multirow{2}{*}{$\begin{array}{l}\text { Global } \\
\text { Rating }\end{array}$} \\
\hline & $\begin{array}{l}\text { Selection } \\
\text { Bias }\end{array}$ & $\begin{array}{l}\text { Study } \\
\text { Design }\end{array}$ & Confounders & Blinding & $\begin{array}{l}\text { Data } \\
\text { Collection } \\
\text { Method }\end{array}$ & $\begin{array}{l}\text { Withdrawals } \\
\text { and } \\
\text { Dropouts }\end{array}$ & \\
\hline Gao K et al. & strong & moderate & strong & moderate & strong & weak & moderate \\
\hline $\begin{array}{l}\text { Hai-Bo Liu } \\
\text { et al. }\end{array}$ & strong & moderate & strong & moderate & strong & weak & moderate \\
\hline $\begin{array}{l}\text { Jiang Li et } \\
\text { al. }\end{array}$ & strong & moderate & strong & moderate & strong & weak & moderate \\
\hline $\begin{array}{l}\text { Wein-ran } \\
\text { Pan et al. }\end{array}$ & strong & moderate & strong & moderate & strong & weak & moderate \\
\hline $\begin{array}{l}\text { Rajaramam } \\
\text { et al. }\end{array}$ & strong & moderate & strong & moderate & strong & weak & moderate \\
\hline $\begin{array}{l}\text { Gaofeng } \\
\text { Xu et al. }\end{array}$ & strong & moderate & strong & moderate & strong & weak & moderate \\
\hline $\begin{array}{l}\text { Xue-Bin Hu } \\
\text { et al. }\end{array}$ & strong & moderate & strong & moderate & strong & weak & moderate \\
\hline $\begin{array}{l}\text { Zhou Lu- } \\
\text { Qiu et al. }\end{array}$ & strong & moderate & strong & moderate & strong & weak & moderate \\
\hline $\begin{array}{l}\text { Custodio } \\
\text { AC et al. }\end{array}$ & strong & moderate & strong & moderate & strong & weak & moderate \\
\hline $\begin{array}{l}\text { Dianhong } \\
\text { W et al. }\end{array}$ & strong & moderate & strong & moderate & strong & weak & moderate \\
\hline $\begin{array}{l}\text { Fan SC et } \\
\text { al. }\end{array}$ & strong & moderate & strong & moderate & strong & weak & moderate \\
\hline $\begin{array}{l}\text { Rajaramam } \\
\text { et al. }\end{array}$ & strong & moderate & strong & moderate & strong & weak & moderate \\
\hline $\begin{array}{l}\text { Caggana et } \\
\text { al. }\end{array}$ & strong & moderate & strong & moderate & strong & weak & moderate \\
\hline $\begin{array}{l}\text { Da-Qing } \\
\text { Chen et al. }\end{array}$ & strong & moderate & strong & moderate & strong & weak & moderate \\
\hline Gao X et al. & strong & moderate & strong & moderate & strong & weak & moderate \\
\hline Hui L. et al. & strong & moderate & strong & moderate & strong & weak & moderate \\
\hline $\begin{array}{l}\text { Luo Ke-Qin } \\
\text { et al. }\end{array}$ & strong & moderate & strong & moderate & strong & weak & moderate \\
\hline $\begin{array}{l}\text { Margaret W } \\
\text { et al. }\end{array}$ & strong & moderate & strong & moderate & strong & weak & moderate \\
\hline $\begin{array}{l}\text { Roberta MC } \\
\text { et al. }\end{array}$ & strong & moderate & strong & moderate & strong & weak & moderate \\
\hline
\end{tabular}




\begin{tabular}{|llllllll|}
\hline Study & \multicolumn{2}{l}{ Component Ratings } & & & & & Global \\
\cline { 2 - 5 } & $\begin{array}{l}\text { Selection } \\
\text { Bias }\end{array}$ & $\begin{array}{l}\text { Study } \\
\text { Design }\end{array}$ & Confounders & Blinding & $\begin{array}{l}\text { Data } \\
\text { Collection } \\
\text { Method }\end{array}$ & $\begin{array}{l}\text { Withdrawals } \\
\text { and } \\
\text { Dropouts }\end{array}$ & \\
\hline $\begin{array}{l}\text { Rodriguez- } \\
\text { Hernandez } \\
\text { I et al. }\end{array}$ & strong & moderate & strong & moderate & strong & weak & moderate \\
$\begin{array}{l}\text { Salnikova } \\
\text { LE et al. }\end{array}$ & strong & moderate & strong & moderate & strong & weak & moderate \\
\hline
\end{tabular}

Of the eleven articles on XRCC1 rs1799782, nine were based on Asian populations. Of the studies on ERCC2 rs13181, five were based on Caucasian populations, four were based on Asian populations, and one was based on both Caucasians and Asians. Only one study was conducted using a Latin-American population (Brazilian) to evaluate the XRCC1 rs1799782 SNP (Table 2). 
Table 2

Summary of characteristics found in the selected studies on XRCC1 rs1799782.

\begin{tabular}{|c|c|c|c|c|c|c|}
\hline AUTHORS & YEAR & $\begin{array}{l}\text { SPECIMEN } \\
\text { STUDIED }\end{array}$ & (n) & $\begin{array}{l}\text { MOLECULAR } \\
\text { ANALYSIS }\end{array}$ & POPULATION & RESULTS \\
\hline Gao K et al. & 2014 & Serum & $\begin{array}{l}326 \\
\times \\
376\end{array}$ & PCR & Asians & No association. \\
\hline $\begin{array}{l}\text { Hai-Bo Liu } \\
\text { et al. }\end{array}$ & 2012 & Serum & $\begin{array}{l}312 \\
\times \\
312\end{array}$ & PCR & Asians & $\begin{array}{l}\text { Increased risk for glioma in } \\
\text { TT genotypes. }\end{array}$ \\
\hline $\begin{array}{l}\text { Jiang Li et } \\
\text { al. }\end{array}$ & 2014 & Serum & $\begin{array}{l}368 \\
\times \\
346\end{array}$ & PCR & Asians & No association. \\
\hline $\begin{array}{l}\text { Wein-ran } \\
\text { Pan et al. }\end{array}$ & 2013 & Serum & $\begin{array}{l}443 \\
\times \\
443\end{array}$ & PCR & Asians & $\begin{array}{l}\text { Increased risk for glioma in } \\
\text { TT genotypes. }\end{array}$ \\
\hline $\begin{array}{l}\text { Rajaramam } \\
\text { et al. }\end{array}$ & 2010 & Serum & $\begin{array}{l}362 \\
\times \\
495\end{array}$ & PCR & Caucasians & Increased risk for gliomas. \\
\hline $\begin{array}{l}\text { Gaofeng } \\
\text { Xu et al. }\end{array}$ & 2014 & Serum & $\begin{array}{l}886 \\
\times \\
886\end{array}$ & PCR & Asians & $\begin{array}{l}\text { Increased risk for glioma in } \\
\text { TT genotypes. }\end{array}$ \\
\hline $\begin{array}{l}\text { Xue-Bin Hu } \\
\text { et al. }\end{array}$ & 2011 & Serum & $\begin{array}{l}127 \\
\times \\
249\end{array}$ & PCR & Asians & Increased risk for gliomas. \\
\hline $\begin{array}{l}\text { Zhou Lu- } \\
\text { Qiu et al. }\end{array}$ & 2011 & Serum & $\begin{array}{l}271 \\
\times \\
289\end{array}$ & PCR & Asians & No association. \\
\hline $\begin{array}{l}\text { Custodio } \\
\text { AC et al. }\end{array}$ & 2011 & Serum & $\begin{array}{l}80 \\
\times \\
100\end{array}$ & PCR & Caucasians & $\begin{array}{l}\text { Increased risk for gliomas. } \\
\text { Presence of the } 194 \text { Trp allele } \\
\text { improved survival. }\end{array}$ \\
\hline $\begin{array}{l}\text { Dianhong } \\
\text { W et al. }\end{array}$ & 2012 & Serum & $\begin{array}{l}624 \\
\times \\
580\end{array}$ & PCR & Asians & No association. \\
\hline $\begin{array}{l}\text { Fan SC et } \\
\text { al. }\end{array}$ & 2016 & Serum & $\begin{array}{l}115 \\
\times \\
228\end{array}$ & PCR & Asians & $\begin{array}{l}\text { Increased risk for gliomas in } \\
\text { Trp/Trp, Arg/Trp + Trp/Trp } \\
\text { patients. }\end{array}$ \\
\hline
\end{tabular}

All the published articles evaluated in our study used serum samples to investigate the peripheral nervous system except one, which used oral mucosa specimens. The method used to detect polymorphisms for all the published studies was polymerase chain reaction (Table 2).

Of the studies on XRCC1 rs1799782, four reported no relationship with the risk of developing gliomas while the other seven reported an association, especially in the presence of the TT genotype and/or the Trp allele (Table 2). Of the studies on ERCC2 rs13181, six reported no association with the risk of gliomas, two reported an increased risk, and the other two reported a decreased risk in the presence of the AGC haplotype or $\mathrm{C}$ allele (Table 3). 
Table 3

Summary of characteristics found in the selected studies on ERCC2 rs13181.

\begin{tabular}{|c|c|c|c|c|c|c|}
\hline AUTHORS & YEAR & $\begin{array}{l}\text { SPECIMEN } \\
\text { MATERIAL }\end{array}$ & (n) & $\begin{array}{l}\text { MOLECULAR } \\
\text { ANALYSIS }\end{array}$ & POPULATION & RESULTS \\
\hline $\begin{array}{l}\text { Rajaramam et } \\
\text { al. }\end{array}$ & 2010 & Serum & $\begin{array}{l}362 \\
\times 495\end{array}$ & PCR & Caucasians & No association. \\
\hline $\begin{array}{l}\text { Caggana et } \\
\text { al. }\end{array}$ & 2001 & Serum & $\begin{array}{l}187 \\
\times 171\end{array}$ & PCR & Caucasians & No association. \\
\hline $\begin{array}{l}\text { Da-Qing Chen } \\
\text { et al. }\end{array}$ & 2012 & Serum & $\begin{array}{l}393 \\
\times 410\end{array}$ & PCR & Asians & $\begin{array}{l}\text { Increased risk for } \\
\text { gliomas. Decreased } \\
\text { mortality. Increased QT } \\
\text { efficacy. }\end{array}$ \\
\hline Gao X et al. & 2015 & Serum & $\begin{array}{l}165 \\
\times 330\end{array}$ & PCR & Asians & $\begin{array}{l}\text { Increased risk for glioma, } \\
\text { recessive and co- } \\
\text { dominant. }\end{array}$ \\
\hline Hui L. et al. & 2014 & Serum & $\begin{array}{l}138 \\
\times 204\end{array}$ & PCR & Asians & No association. \\
\hline $\begin{array}{l}\text { Luo Ke-Qin et } \\
\text { al. }\end{array}$ & 2013 & Serum & $\begin{array}{l}202 \\
\times 68\end{array}$ & PCR & Asians & No association. \\
\hline $\begin{array}{l}\text { Margaret W et } \\
\text { al. }\end{array}$ & 2005 & Oral swab & $\begin{array}{l}450 \\
\times 500\end{array}$ & PCR & $\begin{array}{l}\text { Asians + } \\
\text { Caucasians }\end{array}$ & No association. \\
\hline $\begin{array}{l}\text { Roberta MC et } \\
\text { al. }\end{array}$ & 2009 & Serum & $\begin{array}{l}1015 \\
\times \\
1994\end{array}$ & PCR & Caucasians & $\begin{array}{l}\text { Reduced risk of gliomas } \\
\text { in the AGC haplotype. }\end{array}$ \\
\hline $\begin{array}{l}\text { Rodriguez- } \\
\text { Hernandez I } \\
\text { et al. }\end{array}$ & 2013 & Serum & $\begin{array}{l}115 \\
\times 200\end{array}$ & PCR & Caucasians & $\begin{array}{l}\text { Haplotypes containing } \\
\text { the C allele decreased the } \\
\text { risk of glioblastoma. }\end{array}$ \\
\hline $\begin{array}{l}\text { Salnikova LE } \\
\text { et al. }\end{array}$ & 2013 & Serum & $\begin{array}{l}284 \\
\times 464\end{array}$ & PCR & Caucasians & No association. \\
\hline
\end{tabular}

Five articles reported an increased risk for gliomas for Asian populations in the presence of XRCC1 rs 1799782 and two articles reported an increase in the presence of ERCC2 rs13181. For Caucasian populations, two articles reported an increased risk for gliomas in the presence of the XRCC1 rs1799782 SNP and two articles reported a decreased risk in the presence of ERCC2 rs13181 (Table 2 and Table 3).

The meta-analysis identified an increased risk of gliomas for only the TT genotype of XRCC1 rs1799782 (OR: $\left.1.61,95 \% \mathrm{Cl}: 1.33-1.94 ; p=0.001 ; I^{2}: 0 \%\right)$. Considering the population type, only Asians presented with an increased risk (OR: $1.59,95 \% \mathrm{Cl}: 1.3-1.93 ; \mathrm{p}=0.006 ; \mathrm{I}^{2}: 13.1 \%$ ). For $E R C C 2 \mathrm{rs} 13181$ polymorphisms, increased risks of gliomas were identified for Asians with AC genotypes (OR: $1.53,95 \% \mathrm{Cl}: 1.2-1.97 ; p=0.00057 ; 1^{2}: 91.1 \%$ ) and Caucasians with AC genotypes (OR: 1.16, 95\% Cl: 1.01-1.31; $p=0.02 ; I^{2}: 12.2 \%$ ). For the general population, the CC genotype of ERCC2 rs13181 was also associated with increased risk (OR: 1.83, 95\% Cl: 1.57-2.13; $p<$ $0.001 ; I^{2}: 98 \%$ ), as well as for Caucasians specifically (OR: $2.06,95 \% \mathrm{Cl}: 1.75-1.42 ; \mathrm{p}<0.0001 ; I^{2}: 98.9 \%$ ). There was no relationship identified between the GCC and GT genotypes of ERCC2 rs13181 and the risk of glioma development (Fig. 2 through Fig. 7). 
Among the genotypes of the polymorphisms that showed an increased risk for glioma development, only in the study in Asians with ERCC2 rs13181 AC was not possible to perform the tests of publication bias due to the small number of studies $(<3)$. In the other studies, Begg and Egger test did not show publication bias (ERCC2 rs13181 AC in Caucasians BT $p=0.117 /$ ET p $=0.256$; ERCC2 rs13181 CC in Caucasians BT $p=0.602 / E T p=$ 0.966; XRCC1 rs1799782 TT in Asians BT $p=0.105$ / ET $p=0.281$. However, when analyzing the Funnel Plot, only the results of the studies of XRCC1 rs1799782 TT in Asians and ERCC2 rs13181 AC in Caucasians showed an asymmetric distribution, denoting no publication bias (Fig. 8).

\section{Discussion}

There are four main pathways involved in repairing DNA damage, nucleotide excision repair (NER), base excision repair (BER), double-strand break repair (DSBR), and mismatch repair (MMR). XRCC1 and ERCC2 encode proteins that are involved in the BER and NER pathways, respectively, and polymorphisms in these genes may change a cell's DNA repair efficiency. This in turn may be related to the development of several types of cancers, including lung, colorectal, breast, ovary, and thyroid cancers, esophageal carcinoma, and even brain tumors [9$11]$.

The XRCC group is an important component of the BER system, which is the predominant DNA repair pathway for small errors resulting from oxidation and alkylation damage. The proper functioning of the BER system may prevent the activation of oncogenes or the inactivation of tumor suppression genes and thereby reduce the risk of cancer development. The XRCC1 gene is located on chromosome 19q13.2-13.2, is $33 \mathrm{~kb}$ in size, and consists of 17 exons. The XRCC1 protein coordinates several protein-protein interactions, including those between DNA ligase III, DNA polymerase, and poly ADP-ribose polymerase, which together play an important role in DNA repair. Numerous studies shown a positive correlation between SNPs of XRCC1 and the risk of developing glial neoplasms, and the most common being Arg194Trp (rs1799782), Arg399GIn (rs25487), and Arg280His (rs25489) $[7,9,12,13]$.

Our current systematic review included eleven published articles on XRCC1 rs1799782, which contained contradictory findings. For instance, studies by Gao et al. [7], Li et al. [10], Zhou et al. [14] and Wang et al. [15] reported no association between the XRCC1 rs1799782 SNP and the risk of developing gliomas. However, other studies reported an increased risk, including those by Hu et al. [16] and Rajaraman et al. [17]. Mean while, Liu et al. [18], Xu et al. [9] and Pan et al. [12] reported an increased risk for glioma specific for the TT genotypes in an Asian population. Custodio et al. [20] reported an increased risk for gliomas in Caucasians with the XRCC1 rs1799782 SNP (Brazilian population), but they also observed improved survival in the presence of the 194Trp allele. Finally, in the study published by Fan et al. [8] there was an increased risk for gliomas in participants that had TT or CT + TT genotypes (Table 2) [14-24].

Due to the discrepancies in the published results, we performed this meta-analysis and found for healthy individuals an increased risk for the development of glial tumors only in Asians with the TT genotype of the XRCC1 rs1799782 as an association was not observed with the CT and/or CT + TT genotypes. These results were similar to the meta-analyses by Li et al. [21], He et al. [22], and Zhang et al. [23]. However, in none of those studies was the data analysis broken down by observed population type [25-27]. Contrary to our study, a review by Sun et al. [5], reported an increased risk associated with the TT genotype in the general population, but no association when individually analyzed in the Asian and Caucasian populations [28]. 
Lu et al. [24] reviewed sixteen published papers and reported increased risk only for Asians with TT and TT + CT genotype in their meta-analysis. Xu et al. [25] found an increased risk only in Asians with CT + TT genotype and in both Asians and Caucasians with TT genotype. There are currently also systematic reviews in the literature that include meta-analysis and report a relationship between the XRCC1 rs1799782 polymorphism and its genotypes with the development of glial tumors [31-33].

The ERCC2 gene is located on chromosome 19q13.3 and encodes a protein responsible for DNA repair as part of the NER pathway. There are published reports on the relationship between some ERCC2SNPs and the risk of systemic tumors with the most studied being ERCC2 Lys751GIn (rs13181). This polymorphism is characterized by the replacement of thymine $(T)$ by guanine $(G)$ at the locus 751 , which changes the enzymatic activity of some encoded proteins, such as helicase, and can be associated with several types of cancers, including gastric, esophageal, hepatocellular carcinoma, non-small cell lung, prostate, skin, and bladder cancers, as well as gliomas [6]. Our current study reviewed and analyzed ten published reports that included five based on Asian populations, four based on Caucasian populations, and one that included both populations and the genotypes studied in these reports were AC, CC, GG, and TG.

Similar to the results regarding the XRCC1 polymorphisms, the findings for ERCC2 rs13181 polymorphisms are highly contradictory. Six reports demonstrate no relationship between ERCC2 rs13181 polymorphisms and the risk of developing glial tumors. However, the studies by Gao et al. [7] and Chen et al. [29] reported increased risks of gliomas while the reports by McKean-Cowdin [30] and Rodriguez-Hernandez et al. [11] showed a decrease risk in the presence of the AGC haplotype and C allele, respectively.

Based on meta-analysis, the AC genotypes of ERCC2 rs13181 in Asians and Caucasians and the CC genotypes in Caucasians were associated to an increased risk of gliomas. This result corroborates the findings reported by Qian et al. [6], who reviewed fifteen studies and conducted a meta-analysis [38]. These investigators reported increased risks for the development of glial cell tumors only in Asians with the CC and AC genotypes (Figs. 2 and 3).

In our current review and analysis, the GG and TG genotypes showed no relationship with the development of glial tumors, corroborating the studies by Xin et al. [31] and Zhou et al. [32] (Fig. 2 and Fig. 3). However, contrary results were described in the reviews and meta-analyses by Cui et al. [33] and Jia et al. [34], who found increased risks only in Asian populations and with the TG genotype. On the other hand, Huang et al. [35] found increased risks in the general population for patients with either TG or GG genotypes.

Although the meta-analysis shows the importance of SNPs XRCC1 rs1799782 TT, ERCC2 rs13181 AC and CC in the development of gliomas in certain populations, the high heterogeneity between studies and the presence of publication biases evidenced in some Plot Funnel, show the need for further multicenter studies with larger samples, more uniform methodologies and research with different ethnic groups in order to establish the association of these polymorphisms with the risk of developing gliomas.

The studies presented in our current review and analysis had limitations, which thereby contributed to limitations of our study. These included the fact that most all of them used only one population type, which prevents the extrapolation of the results to other ethnic groups. Furthermore, in most of the studies, the samples were collected from only a single hospital, increasing the potential for selection bias. Finally, in most of the studies the 
interactions between genes, environmental factors, and even the loci of the polymorphisms were not considered, which are factors that may influence the risk of developing gliomas.

\section{Conclusion}

In the present study, TT genotypes of XRCC1 rs1799782 in Asians and ERCC2 rs13181 polymorphisms with AC genotypes in Asians and Caucasians and CC genotypes in Caucasians are associated with increased risk for gliomas that may benefit these patients with early diagnostic and therapeutic strategies.

\section{Abbreviations}

XRCC1

X-ray repair cross-complementing group 1; ERCC2:excision repair cross-complementation group 2; SNPs:single nucleotide polymorphisms; PRISMA:Preferred Reporting Items for Systematic Reviews and Meta-Analyses; PICOS:The Population, Intervention, Comparison, Outcome and Study design; OR:odds ratios; Cl:confidence interval; WHO:World Health Organization; NER:nucleotide excision repair; BER:base excision repair; DSBR:doublestrand break repair; MMR:mismatch repair; T:thymine; G:guanine; BT:Begg Test; ET:Egger Test.

\section{Declarations}

\section{Ethics approval and consent to participate}

Not applicable

\section{Consent for publication}

Not applicable.

\section{Availability of data and materials}

All data generated in this analysis are available from the corresponding author.

\section{Competing interests}

The authors declare that they have no competing interests.

\section{Funding}

No funding was obtained for this study.

\section{Author Contributions}

$C B$ and $B B$ conceived and designed the study;

FA and EJ provided study materials and tools; 
$R J, L C, V C, A C, E B, R O, C B B B$ were responsible for the collection and assembly of data, data analysis, and interpretation;

$F C, P V$, dos $A R, A L$ was involved in writing the manuscript;

$C B, B B$ and $L H$ revised the manuscript.

\section{all authors have read and approved the manuscript}

\section{Acknowledgments}

The authors thank to Postgraduate Program of the Northeast Network of Biotechnology (RENORBIO), the largest network Program in Brazil for qualification of doctors in Biotechnology.

\section{References}

1. Pollack IF, Randall MS, Kristofik MP, Kelly RH, Selker RG, Vertosick FT Jr. Effect of tamoxifen on DNA synthesis and proliferation of human malignant glioma lines in vitro. Cancer Res. 1990;50:7134-8.

2. Patel S, DiBiase S, Meisenberg B, Flannery T, Patel A, Dople A, et al. Phase I clinical trial assessing temozolomide and tamoxifen with concomitant radiotherapy for treatment of high-grade glioma. Int $\mathrm{J}$ Radiat Oncol Biol Phys. 2012;82:739-42. doi:10.1016/j.ijrobp.2010.12.053.

3. Tang P, Roldan G, Brasher PM, Fulton D, Roa W, Murtha A, et al. A phase II study of carboplatin and chronic high-dose tamoxifen in patients with recurrent malignant glioma. J Neurooncol. 2006;78:311-6. doi:10.1007/s11060-005-9104-y.

4. 4. Uematsu M, Ohsawa I, Aokage T, NiahimKI k, Matsumoto K, Takahashi H, et al. Prognostic significance of the immunohistochemical index of survivin in glioma: a comparative study with the MIB-1 index. J Neurooncol. 2005;72: 231-8. doi:10.1007/s11060-004-2353-3.

5. Sun JY, Zhang CY, Zhang ZJ, Dong YF, Zhang AL, Dong YF, et al. Association between XRCC1 gene polymorphisms and risk of glioma development: a meta-analysis. Asian Pac J Cancer Prev. 2012;13:47838. doi:10.7314/apjcp.2012.13.9.4783.

6. Qian T, Zhang B, Qian C, He Y, Li Y. Association between common polymorphisms in ERCC gene and glioma risk: A meta-analysis of 15 studies. Med (Baltim). 2017;96:e6832. doi:10.1097/MD.0000000000006832.

7. Gao X, Tang YJ, Zhang GF, Yu L, Qi ST. ERCC2 rs13181 polymorphism association with glioma susceptibility in a Chinese population. Genet Mol Res 2016; 15(2). doi:10.4238/gmr.15027585.

8. Fan SC, Zhou JG, Yin JZ. Investigation of the role of XRCC1 genetic polymorphisms in the development of gliomas in a Chinese population. Genet Mol Res 2016;15:10.4238/gmr.15038268. doi:10.4238/gmr.15038268.

9. Xu GZ, Liu Y, Zhang Y, Yu J, Diao B. Correlation between VEGFR2 rs2071559 polymorphism and glioma risk among Chinese population. Int J Clin Exp Med. 2015;8(9):16724-8.

10. Li J, Qu Q, Qu J, Wei-Ming L, You-Zhi WShang-Yuan,H, et al. Association between XRCC1 polymorphisms and glioma risk among Chinese population. Med Oncol. 2014;31:186-90. doi:10.1007/s12032-014-0186-2.

11. Rodriguez-Hernandez I, Perdomo S, Santos-Briz A, Garcia JL, Gomez-Moreta JA, Cruz JJ, et al. Analysis of DNA repair gene polymorphisms in glioblastoma. Gene. 2014;536:79-83. doi:10.1016/j.gene.2013.11.077. 
12. Pan WR, Li G, Guan JH. Polymorphisms in DNA repair genes and susceptibility to glioma in a chinese population. Int J Mol Sci. 2013;14:3314-24. doi:10.3390/ijms14023314.

13. Gao K, Mu SQ, Wu ZX. Investigation of the effects of single-nucleotide polymorphisms in DNA repair genes on the risk of glioma. Genet Mol Res. 2014;13:1203-11. doi:10.4238/2014.February.27.5.

14. Zhou LQ, Ma Z, Shi XF, Yin XL, Huang KX, Jiu ZS, et al. Polymorphisms of DNA repair gene XRCC1 and risk of glioma: a case-control study in Southern China. Asian Pac J Cancer Prev. 2011;12:2547-50.

15. Wang D, Hu Y, Gong H, Li J, Ren Y, Li G, et al. Genetic polymorphisms in the DNA repair gene XRCC1 and susceptibility to glioma in a Han population in northeastern China: a case-control study. Gene. 2012;509:223-7. doi:10.1016/j.gene.2012.08.023.

16. Hu XB, Feng Z, Fan YC, Xiong ZY, Huang QW. Polymorphisms in DNA repair gene XRCC1 and increased genetic susceptibility to glioma. Asian Pac J Cancer Prev. 2011;12:2981-4.

17. Rajaraman P, Hutchinson A, Wichner S, Black PM, Fine HA, Loeffler JS, et al. DNA repair gene polymorphisms and risk of adult meningioma, glioma, and acoustic neuroma. Neuro Oncol. 2010;12:37-48. doi:10.1093/neuonc/nop012.

18. Liu H-B, Peng Y-P, Dou C-W, Su X-L, Gao N-K, Tian F-M, et al. Comprehensive Study on Associations Between Nine SNPs and Glioma Risk. Asian Pacific J Cancer Prev. 2012;10:4905-8.

19. Xu G, Wang M, Xie W, Bai X. Three polymorphisms of DNA repair gene XRCC1 and the risk of glioma: a casecontrol study in northwest China. Tumour Biol. 2014;35:1389-95. doi:10.1007/s13277-013-1191-3.

20. Custódio AC, Almeida LO, Pinto GR, Santos MJ, Almeida JRW, Clara CA, et al. Analysis of the polymorphisms XRCC1Arg194Trp and XRCC1Arg399GIn in gliomas. Genet Mol Res. 2011;10:1120-9. doi:10.4238/vol10$2 \mathrm{gmr} 1125$.

21. Li M, Zhou Q, Tu C, Jiang Y. A meta-analysis of an association between the XRCC1 polymorphisms and gliomas risk. J Neurooncol. 2013;111:221-8. doi:10.1007/s11060-012-1022-1.

22. He LW, Shi R, Jiang L, Zeng Y, Ma WL, Zhou JY. XRCC1 gene polymorphisms and glioma risk in Chinese population: a meta-analysis. PLoS One. 2014;9:e111981. doi:10.1371/journal.pone.0111981.

23. Zhang H, Liu H, Knauss JL. Associations between three XRCC1 polymorphisms and glioma risk: a metaanalysis. Tumour Biol. 2013;34:3003-13. doi:10.1007/s13277-013-0865-1.

24. Lu JT, Deng AP, Song J, Zhang L, Luo J. Reappraisal of XRCC1 Arg194Trp polymorphism and glioma risk: a cumulative meta-analysis. Oncotarget. 2017;8:21599-608. doi:10.18632/oncotarget.15376.

25. Xu C, Chen P, Liu W, Gu AH, Wang XR. Association between the XRCC1 Arg194Trp polymorphism and glioma risk: an updated meta-analysis. Asian Pac J Cancer Prev. 2014;15:7419-24.

doi:10.7314/apjcp.2014.15.17.7419.

26. Jiang L, Fang X, Bao Y, ZXhou JY, Shen XY, Ding MH, et al. Association between the XRCC1 polymorphisms and glioma risk: a meta-analysis of case-control studies. PLoS One. 2013;8:e55597.

doi:10.1371/journal.pone.0055597.

27. Liu K, Jiang Y. Polymorphisms in DNA Repair Gene and Susceptibility to Glioma: A Systematic Review and Meta-Analysis Based on 33 Studies with 15 SNPs in 9 Genes. Cell Mol Neurobiol. 2017;37:263-74. doi:10.1007/s10571-016-0367-y.

28. Zhang L, Wang Y, Qiu Z, Luo J, Zhou Z, Shu W. The XRCC1 Arg194Trp polymorphism is not a risk factor for glioma: A meta-analysis involving 1,440 cases and 2,562 controls. Exp Ther Med. 2012;4:1057-62. 
doi:10.3892/etm.2012.716.

29. Chen DQ, Yao DX, Zhao HY, Yang SJ. DNA repair gene ERCC1 and XPD polymorphisms predict glioma susceptibility and prognosis. Asian Pac J Cancer Prev. 2012;13:2791-4. doi:10.7314/apjcp.2012.13.6.2791.

30. McKean-Cowdin R, Barnholtz-Sloan J, Inskip PD, Ruder AM, Butler M, Rajaraman P, et al. Associations between polymorphisms in DNA repair genes and glioblastoma. Cancer Epidemiol Biomarkers Prev. 2009;18:1118-26. doi:10.1158/1055-9965.EPI-08-1078.

31. Xin Y, Hao S, Lu J, Wang Q, Zhang L. Association of ERCC1 C8092A and ERCC2 Lys751GIn polymorphisms with the risk of glioma: a meta-analysis. PLoS One. 2014;9:e95966. doi:10.1371/journal.pone.0095966.

32. Zhou CX, Zhao JH. Systematic review on the association between ERCC1 rs3212986 and ERCC2 rs13181 polymorphisms and glioma risk. Genet Mol Res. 2015;14:2868-75. doi:10.4238/2015.March.31.17.

33. Cui QK, Zhu JX, Liu WD, Wang YH, Wang ZG. Association of ERCC1 rs3212986 \& ERCC2 rs13181 polymorphisms with the risk of glioma. Pak J Med Sci. 2014;30:1409-14. doi:10.12669/pjms.306.5221.

34. Jia TL, Wu HJ, Wang HB, Ma WB, Xing B. Association between the ERCC2 rs13181 polymorphism and the risk of glioma: a meta-analysis. Genet Mol Res. 2015;14:12577-84. doi:10.4238/2015.October.19.1.

35. Huang LM, Shi X, Yan DF, Zheng M, Deng YJ, Zheng WC, et al. Association between ERCC2 polymorphisms and glioma risk: a meta-analysis. Asian Pac J Cancer Prev. 2014;15:4417-22.

doi:10.7314/apjcp.2014.15.11.4417.

36. Legends.

\section{Figures}




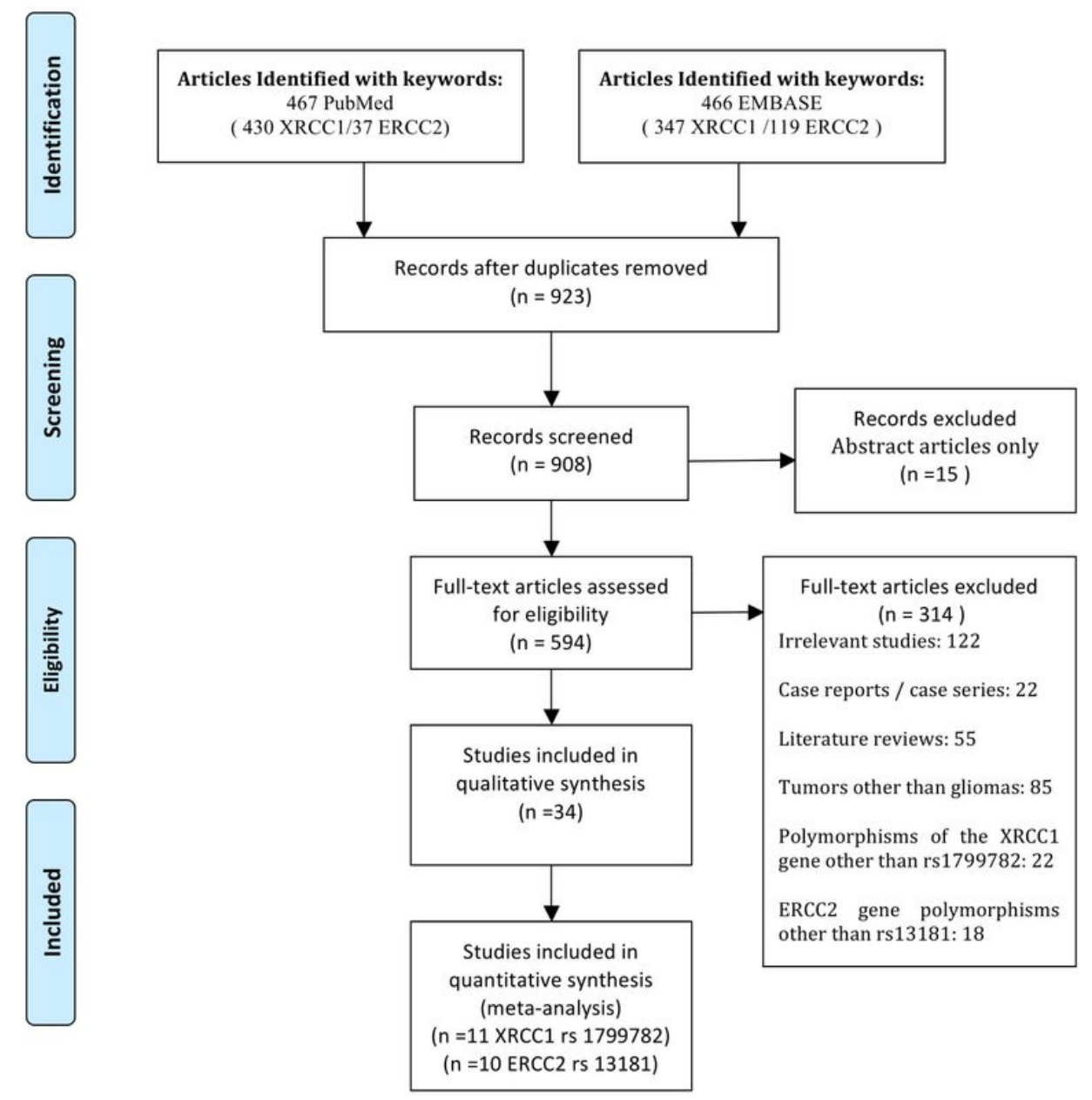

\section{Figure 1}

Flow diagram illustrating the search strategy 
A

XRCC1 rs1799782 (T/T)

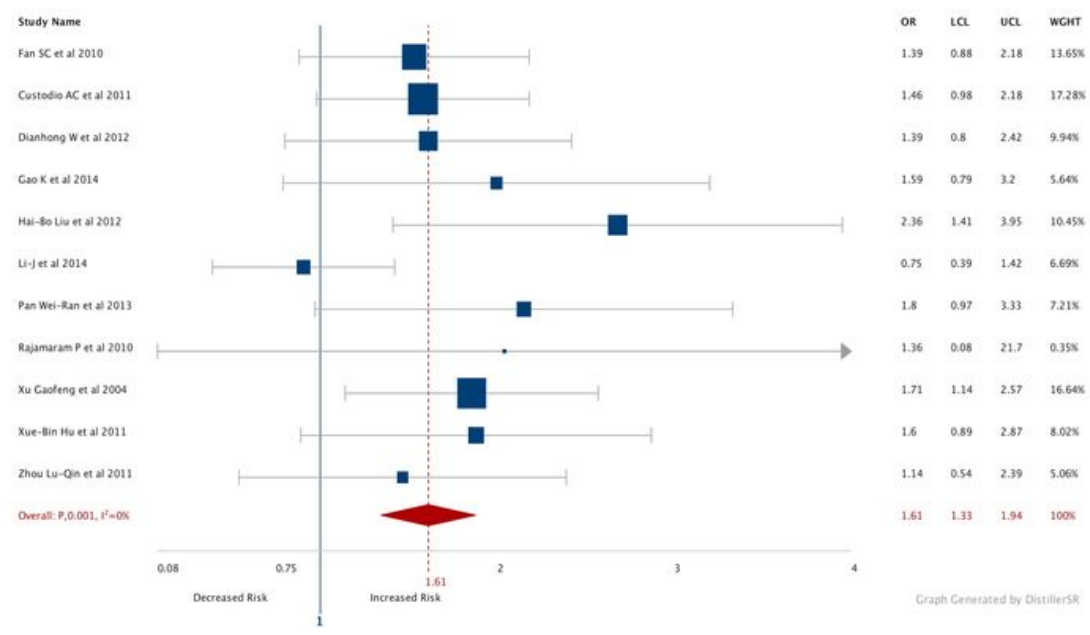

B

XRCC1 rs 1799782 TT Asiáticos

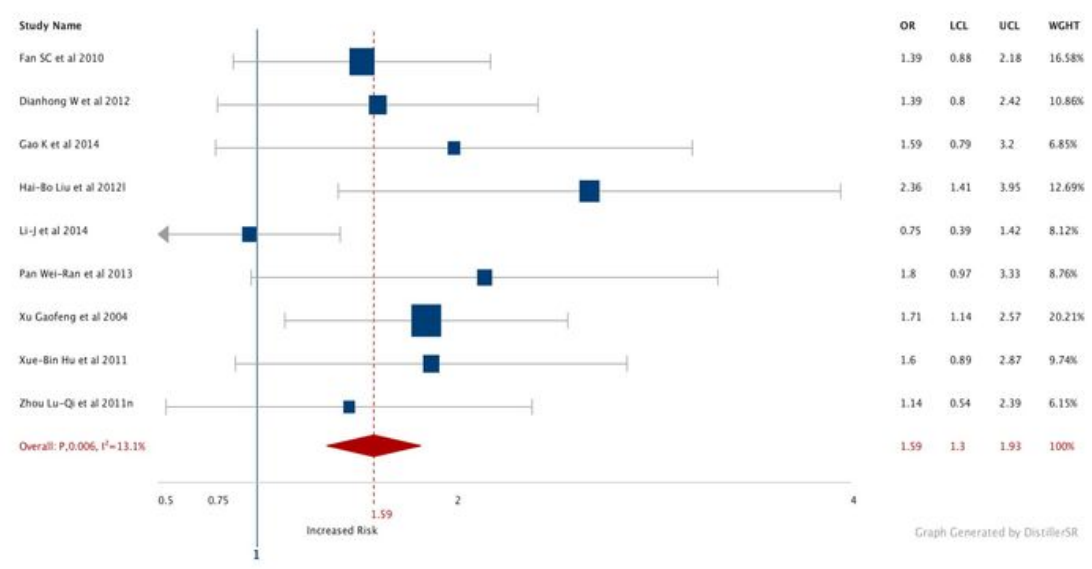

C

XRCC1 rs1799782 TT Caucasians

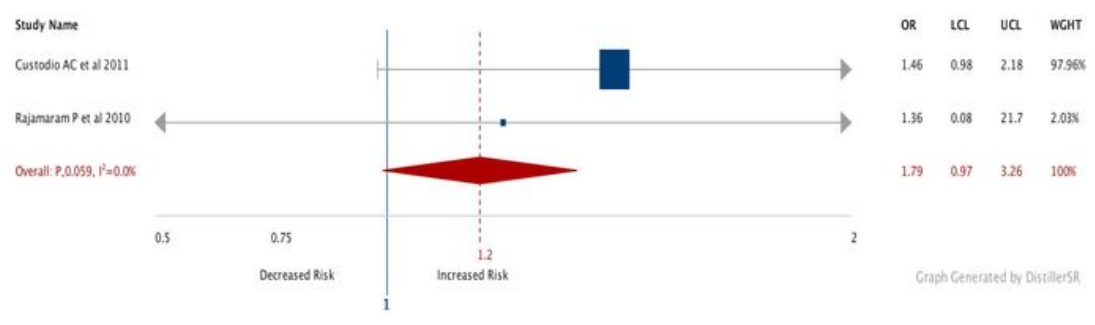

Figure 2

Forest plots. ORs with 95\% Cl for XRCC1 rs1799782 TT and the risk of glioma.Legend: (A) General population. (B) Asian population. (C) Caucasian population. 
A

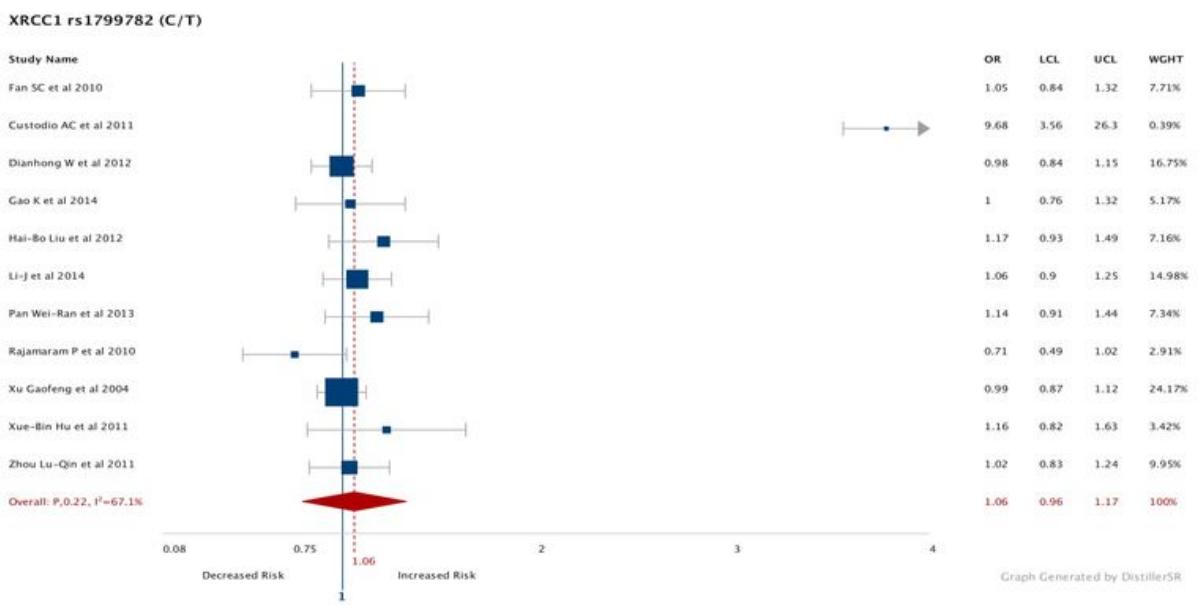

B

XRCC1 rs1799782 CT Asians

Study Name

Fan scet at 2010

Dianhong wet at 2012

G20 ket al 2014

Mai-eo Liv et at 2012

ujet at 2014

Pan we-kan et al 2013

Xu Croteng er al 2014

Xue-din Hu et al 2011

zhow Lu-Con et al 2011

Overall: $: 0.21, P^{2}=0.00$

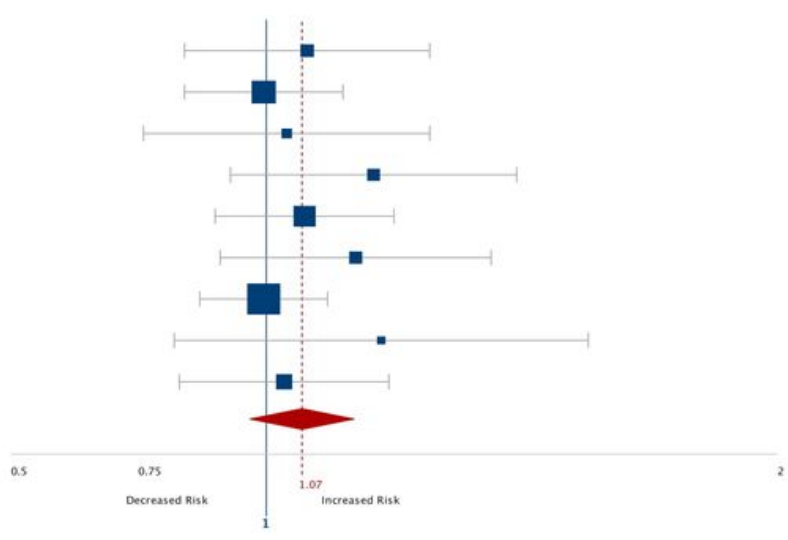

or La va wCHT

$\begin{array}{llll}1.05 & 0.84 & 1.32 & 7.97 \%\end{array}$

$\begin{array}{llll}0.98 & 0.84 & 1.15 & 17.32 \times\end{array}$

$\begin{array}{llll}1 & 0.76 & 1.32 & 5.35 \mathrm{x}\end{array}$

$\begin{array}{llll}1.17 & 0.93 & 1.49 \quad 7.41 \times\end{array}$

$\begin{array}{llll}1.06 & 0.9 & 1.25 & 15.49 \mathrm{X}\end{array}$

$\begin{array}{llll}1.14 & 0.91 & 1.44 & 7.596\end{array}$

$\begin{array}{llll}0.99 & 0.87 & 1.12 \quad 25 x\end{array}$

$\begin{array}{llll}1.16 & 0.82 & 1.63 & 3.53 \mathrm{x}\end{array}$

$\begin{array}{llll}1.02 & 0.83 & 1.24 & 10.35\end{array}$

$\begin{array}{llll}1.07 & 0.96 & 1.17 & 100 x\end{array}$

XRCC1 rs1799782 CT Caucasians
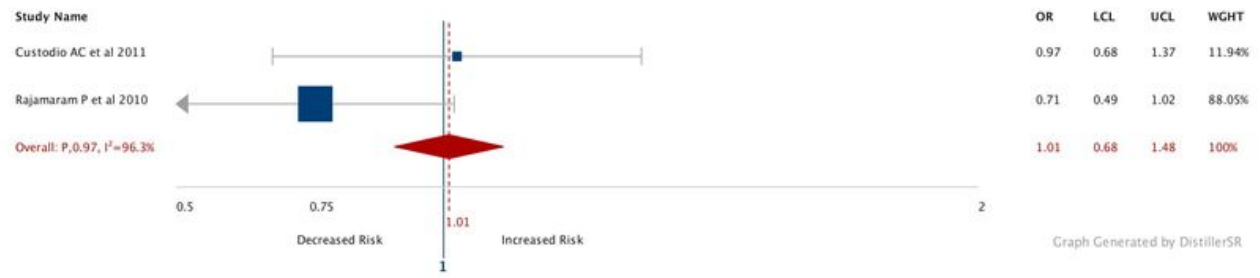

\section{Figure 3}

Forest plots. ORs with 95\% Cl for XRCC1 rs1799782 CT and the risk of glioma. Legend: (A) General population. (B) Asian population. (C) Caucasian population. 


\section{A}

XRCC1 rs $1799782(T T+C T)$

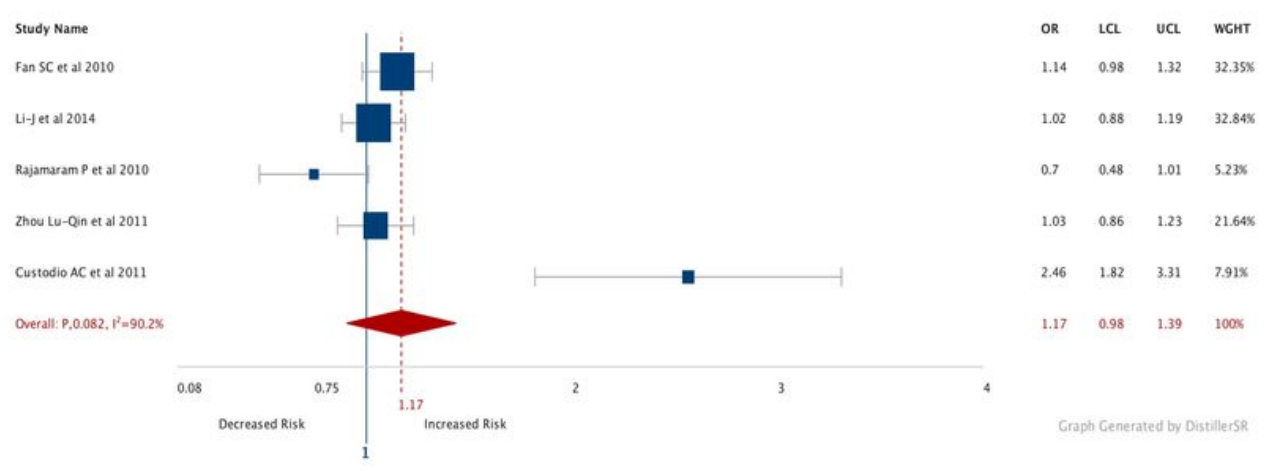

B

XRCC1 rs1799782 (TT+CT) Asians

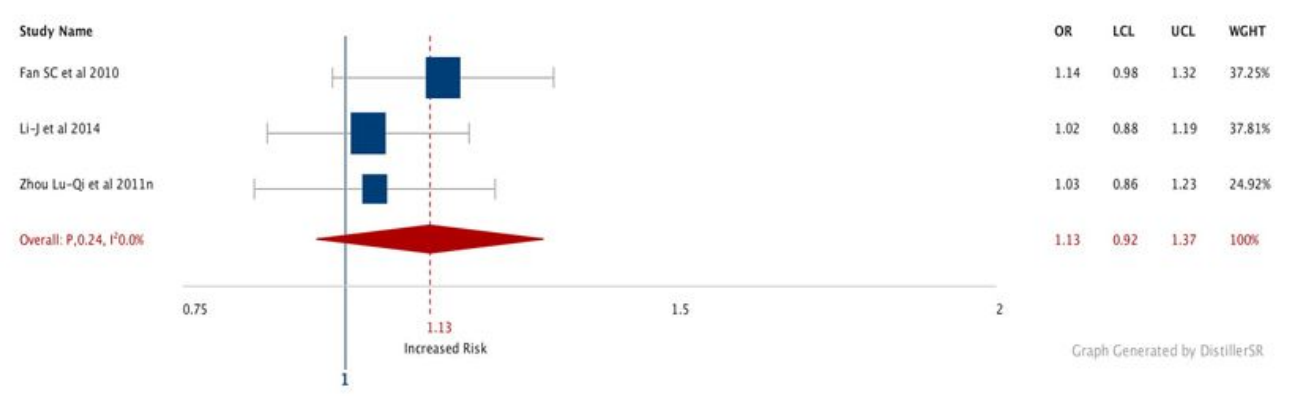

C

XRCC1 rs1799782 (TT+CT) Caucasians

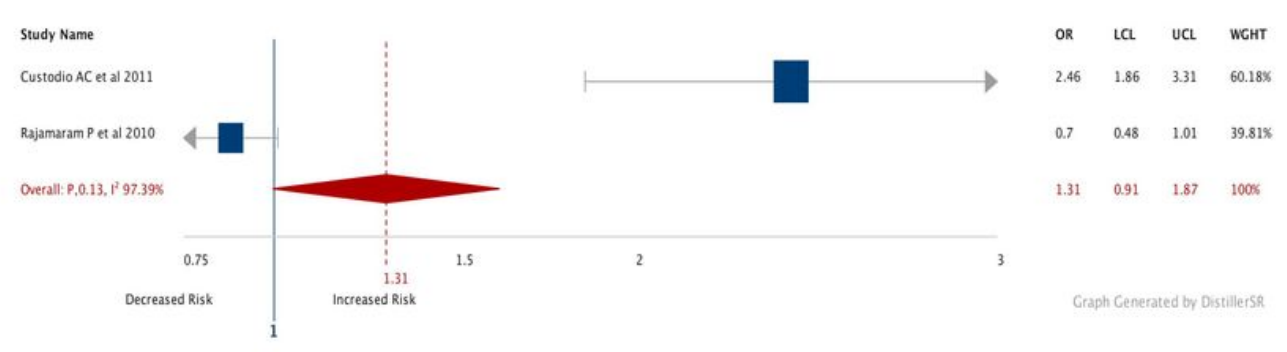

\section{Figure 4}

Forest plots. ORs with 95\% Cl for XRCC1 rs1799782 TT+CT and the risk of glioma. Legend: (A) General population. (B) Asian population. (C) Caucasian population. 
ERCC2 rs13181 (AC)

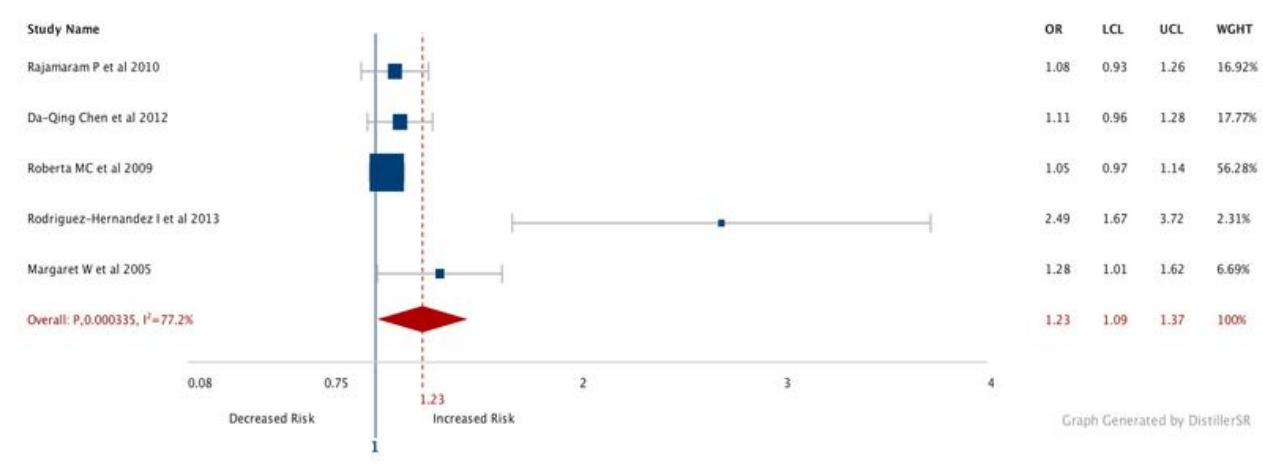

B

ERCC2 rs13181 AC Asians

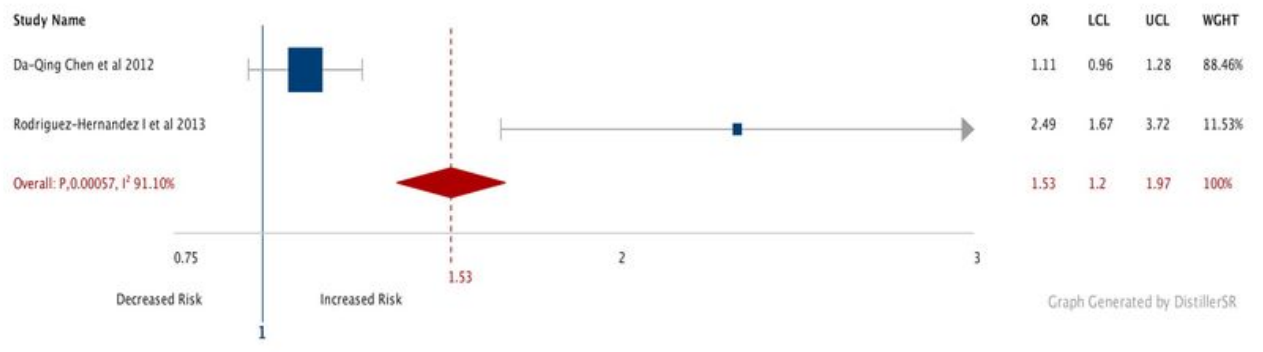

C

ERCC2 rs13181 AC Caucasians
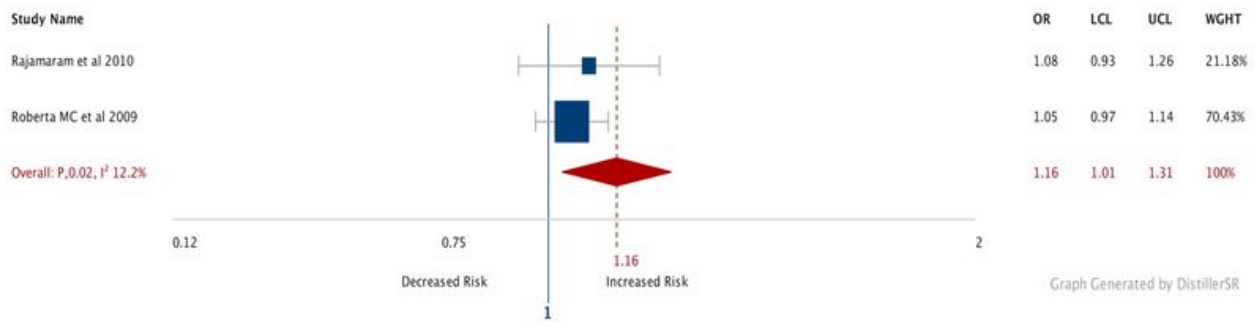

\section{Figure 5}

Forest plots. ORs with 95\% Cl for ERCC2 rs13181 AC and the risk of glioma. Legend: (A) General population. (B) Asian population. (C) Caucasian population. 
ERCC2 rs 13181 (CC)

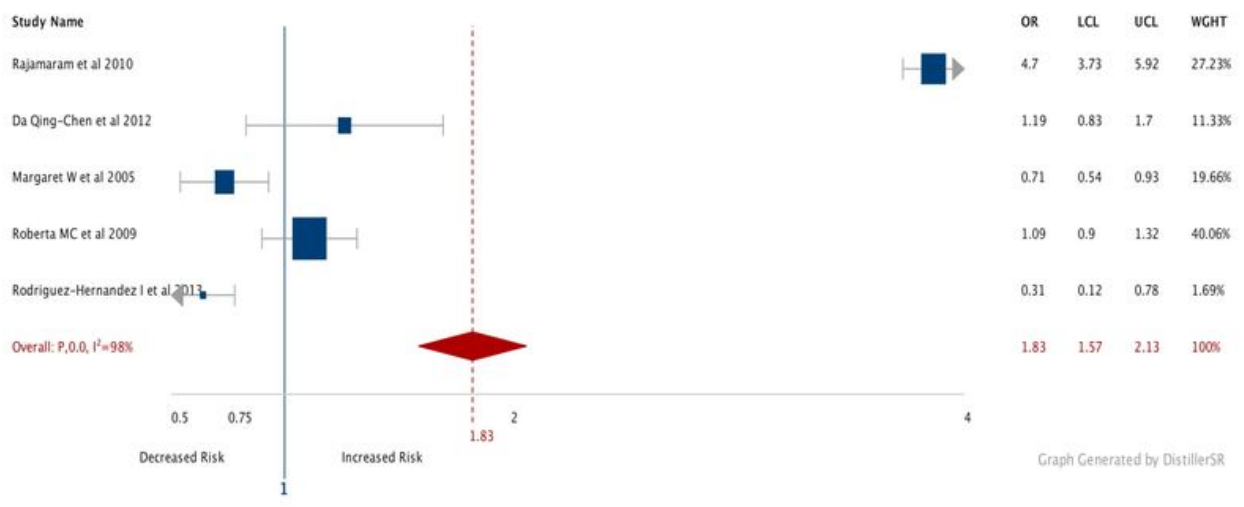

B

ERCC2 rs13181 CC Asians

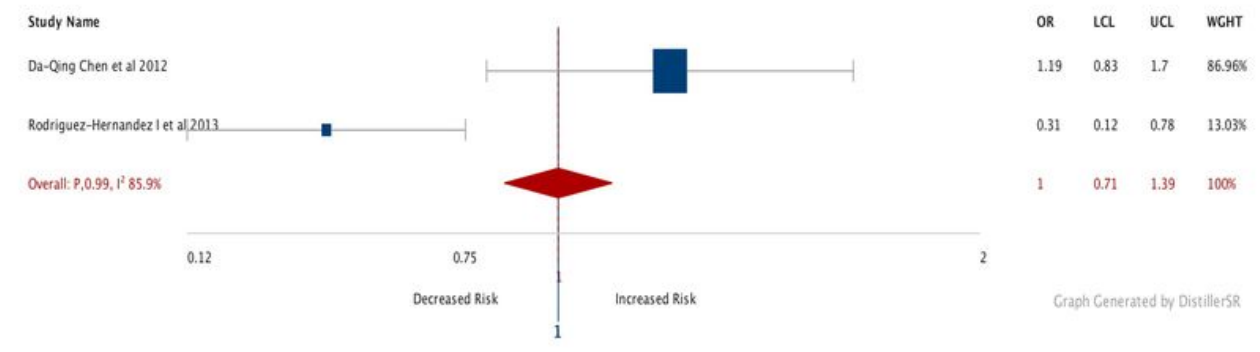

C

ERCC2 rs13181 cC Caucasians

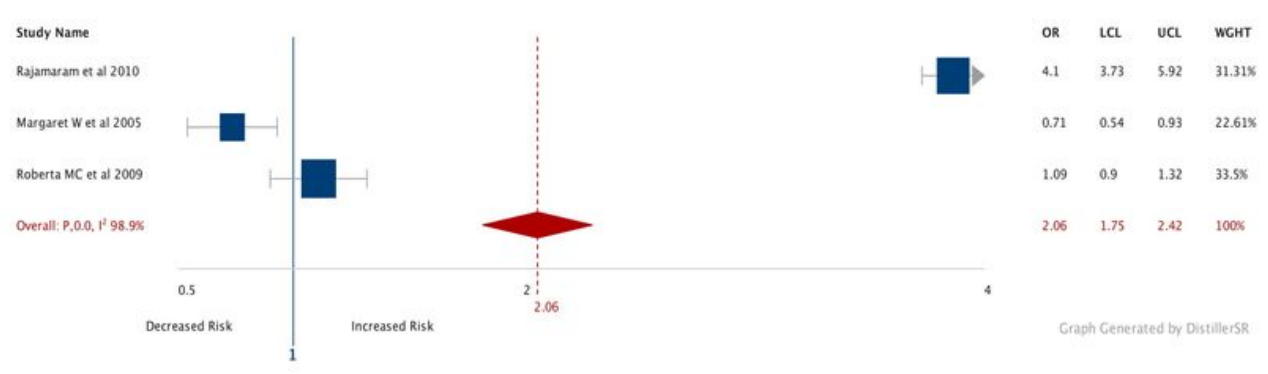

\section{Figure 6}

Forest plots. ORs with 95\% Cl for ERCC2 rs $13181 \mathrm{CC}$ and the risk of glioma. Legend: (A) General population. (B) Asian population. (C) Caucasian population. 
ERCC2 rs 13181 (GC)

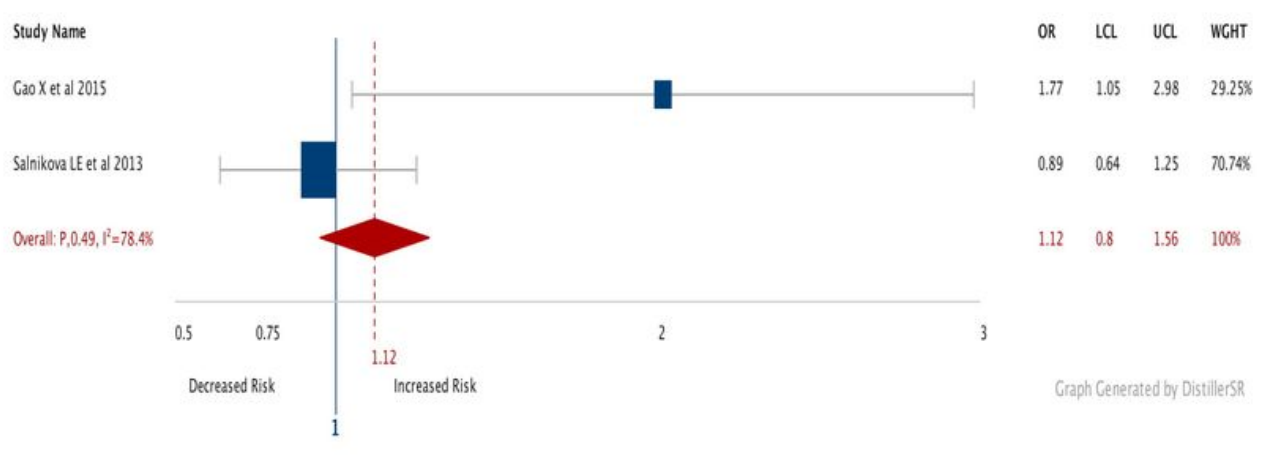

B

ERCC2 rs 13181 (TC)

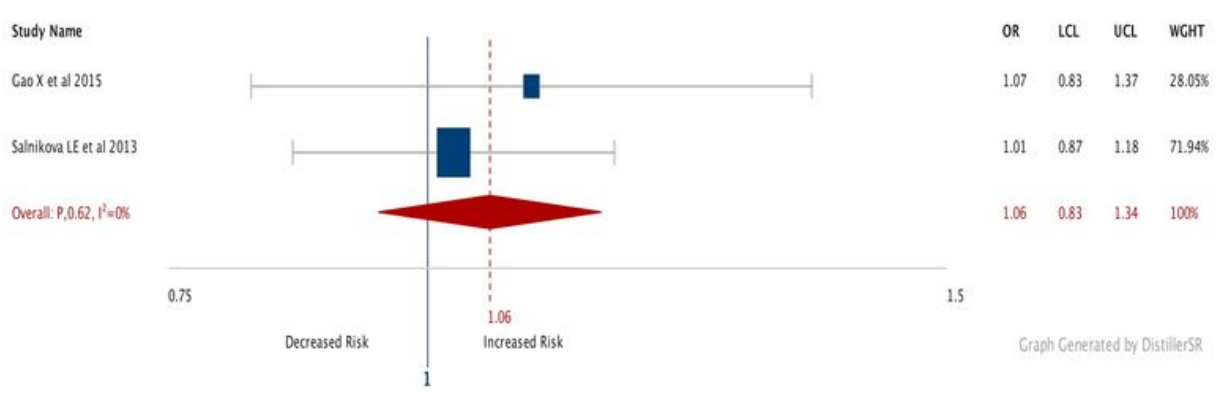

\section{Figure 7}

Forest plots. ORs with 95\% Cl for ERCC2 rs13181 and the risk of glioma. Legend: (A) GG genotype. (B) GT genotype. 

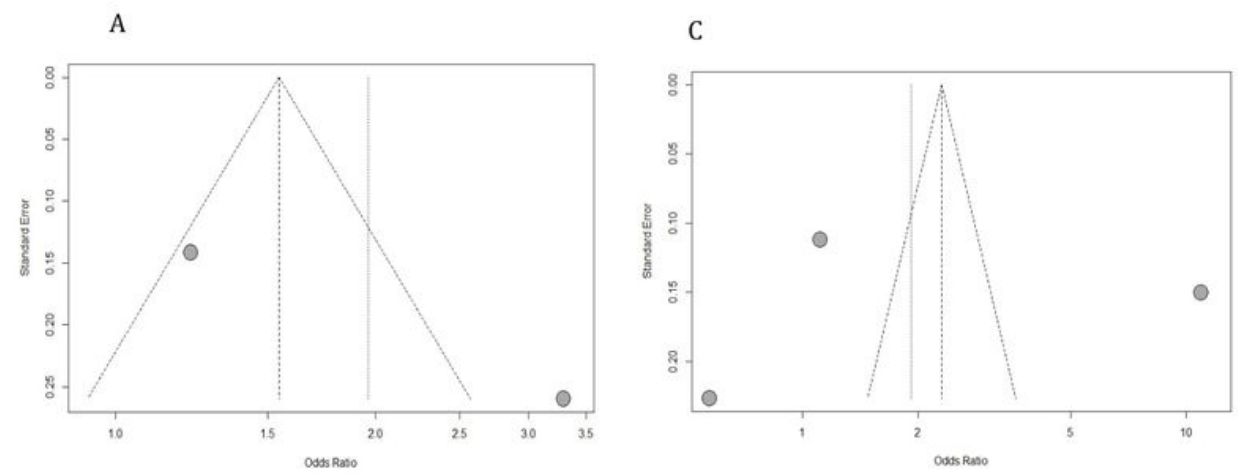

B

D
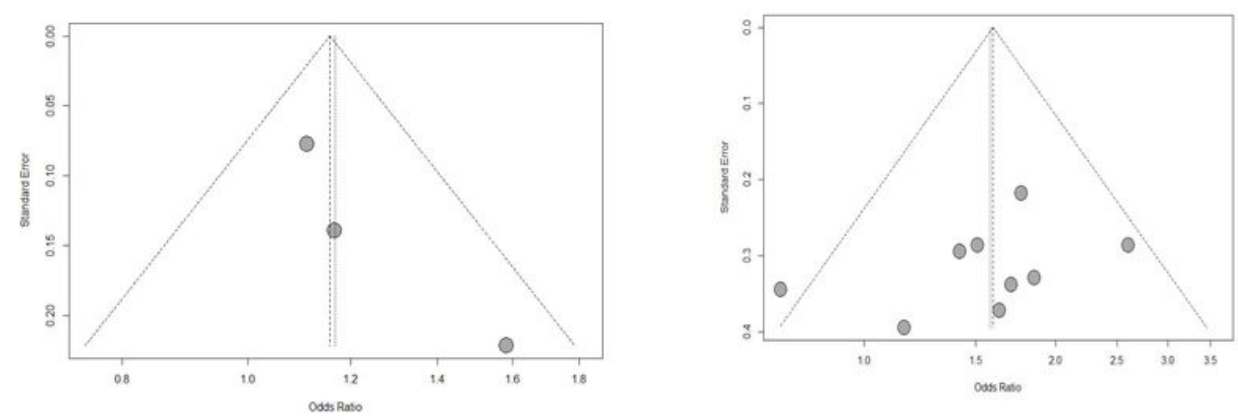

\section{Figure 8}

Funnel Plots analysis: (A) ERCC2 rs13181 AC Asians. (B) ERCC2 rs13181 AC Caucasians. (C) ERCC2 rs13181 CC Caucasians. (D) XRCC1 rs1799782 TT Asians.

\section{Supplementary Files}

This is a list of supplementary files associated with this preprint. Click to download.

- PRISMA2009checklist.doc 